\title{
COMPETENCIES OF SUCCESSFUL CONSTRUCTION PROJECT MANAGERS IN LAO PDR
}

\author{
Phonepaseuth Inthasone and Phithagorn Thanitbenjasith \\ Business Administration Department, Faculty of Business Administration, \\ North - Chiang Mai University, Thailand
}

\begin{abstract}
This research aimed to explore the essential competencies of successful construction project managers in the Lao People's Democratic Republic (Lao PDR). It used constructivism for knowledge claim along with application of phenomenological strategies of inquiry. The author collected data from 3 groups of key informants: 1) construction project managers of construction companies 2) entrepreneurs, executives, project owners and construction project investors, 3) executives and board of directors of construction association. They were chosen by the author using purposive sampling method, while the interview form was the research tool. The data were analyzed and verified by means of content analysis and triangulation, respectively. Besides, the collected data were also interpreted to ensure their reliability. The study results showed that competencies of successful construction project managers in Lao PDR could be divided into two categories: 1) core competencies including knowledge (9 sub-competencies), skills/abilities (9 sub-competencies) and attributes (8 subcompetencies); and 2) successful competencies comprising knowledge (5 subcompetencies), skills/abilities (23 sub-competencies) and attributes (7 subcompetencies). In this regard, those competencies could effectively be developed into a competency model of successful construction project managers in Lao PDR.
\end{abstract}

Key words: Competency, Construction, Lao PDR, Project Manager, Successful.

Cite this Article: Phonepaseuth Inthasone and Phithagorn Thanitbenjasith, Competencies of Successful Construction Project Managers in Lao PDR, International Journal of Management, 11(12), 2020, pp 483-491.

http://iaeme.com/Home/issue/IJM?Volume $=11 \&$ Issue $=12$

\section{INTRODUCTION}

\subsection{Background and Importance of Research}

Since 1975, Lao PDR has adopted a national development model in accordance with socialist economic development guidelines or economic system in which the state controls economic activities with the aim of creating fair distribution of products. Its economic system reform 
towards more liberalized one, begun in 1986, grants the private sector with the right of ownership of the means of production and freedom to conduct economic activities. The "New Economic Mechanism" policy is introduced to foster greater economic relations with foreign countries. At present, Lao PDR's economic situation enjoys constant growth with the average rate of Gross Domestic Product (GDP) in 2015-2017 at 7.3\% and the prediction of GDP in 2020 at 7.1\% (International Monetary Fund, 2018). Besides, Lao PDR's national development is reflected in the National Economic and Social Development Plans No. 7 (2011-2015) and No. 8 (2016-2020) focusing on investments in domestic industries and public utilities for economic development e.g. electricity, communication and transportation systems Many construction projects can be found across Lao PDR, which receives financial aids from various countries for infrastructure and public utility development supporting the economic expansion and growth. In 2016, the Chinese and Lao PDR governments have collaboration of the development of transport routes, rail transport system and high-speed train to reduce inequality between cities and communities; to achieve inclusive and equitable growth; and to maximize efficient management and use of natural resources (Thai Business Information Center in Laos, 2017). Despite the goal to develop Lao PDR to escape from being the Least Developed Country (LDC) within 2020, it fails to efficiently meet targets specified in strategies since investments are not as planned. This is reflected in the World Bank's Ease of Doing Business Index revealing that Lao PDR is ranked 141 out of 190 countries (World Bank, 2017). Thus, Lao PDR needs to improve its transport, environment, infrastructure and public utilities necessary for operating business. With the said supporting factors, the construction industry, especially construction and subcontracting businesses in Lao PDR, plays an important role and likely enjoys rapid expansion to support development of various fundamental systems for national development.

Construction projects are not only the key to Lao PDR's economic expansion but also the central factor in driving national development towards goal achievement under the $8^{\text {th }}$ National Economic and Social Development Plan. Due to the importance of construction industry to Lao PDR's economy, the enterprise or construction business has to be prepared and adapted to ongoing external and internal factors, especially those key resources for construction project e.g., labor, machinery, materials, capital, practice and management (Halpin \& Senior, 2012). This is for the successful construction projects in accordance with targets despite possible constraints: budget, schedule and quality (Chua \& Kao, 2009).

The construction is a project in which project directors or managers play a key role (Siam University, 2010). The construction projects may also have different features depend on type and complexity of each project (The Engineering Institute of Thailand, 2009). The pursuit of a construction project involves several phases e.g., feasibility study, design, procurement, construction, initial use, actual use and end of building's life (Donal \& Boyd, 2016). Moreover, the construction operations are complicated and difficult and problems related to construction project management are as follow: ambiguous and incomplete employment agreement, lack of suitable coordination or communication system (Al-Hammad, 2000), construction management knowledge and skills (Liu, Shen et al., 2004) and conflicts among project stakeholders. As the construction project management comprises many parties such as project owners (fund owners), architects, engineers, contractors, project managers, employers or developer, a possibility of management problems is high because all concerned parties focus on the completion of construction project under constraints of budget, schedule and quality (Chua \& Kao, 2009; Iyer \& Jha, 2005). This agrees with past studies, which reveal that the quality of construction project management fails to satisfy the project owners' expectations ( $\mathrm{Ng}$ et al., 2005). Possible causes for such problems are, for example, engineers with poor knowledge and inefficient project management (Shebob, Dawood et al., 2011), unclear work designation and communication problems (Deming, 1982), etc. 
Regarding Lao PDR's construction industry, most entrepreneurs (98\%) are Small and Medium-sized Enterprises (SMEs), while the large one's account for 2\% (Ministry of Industry and Trade, 2017). Furthermore, there is no applicable law in construction industry requiring construction entrepreneurs to have professional engineering license for construction control. As a result, the supervision of construction business lacks a clear direction and faces with difficulties in quality control. The entry into and leave from this industry are relatively easy making it difficult to develop. Therefore, project managers need to have a good operational planning to deal with different aspects of changes such as risk management, cost control planning and selection of right technology. The project managers' focus on such matter is important. Nonetheless, as many executives in construction industry are from small-sized enterprises, they have certain limitations due to their less work experience and lack of access to manufacturing technology and of proper management.

During the government led by Mr. Thonglun Sisoulid, Prime Minister of Laos, "ThreeOpen Policy" ('opening doors', 'opening obstacles' and 'being open-minded') is introduced to facilitate business operations for constant development of the country in all areas (Office of the Prime Minister of Lao PDR). Its construction industry is expected to grow significantly but, at the same time, the shortage and rising labor cost of at the level of worker, foreman, engineer, and project manager are found resulting in discontinuity of planned constructions in public and private sectors (Department of Public Works and Town \& Country Planning, Lao PDR, 2017). In particular, the real estate price becomes higher, while large-scale government projects exceed the capacity of contractors and labors in handling and delivering works on time. Besides, project owners and contractors have to bear some construction material costs that are likely to rise such as cements, tiles and wood products (Department of Import-Export, Ministry of Industry and Trade, Lao PDR, 2016). This is consistent with the study of Phanomphai Naipai (1999), which mentions that construction restrictions or work capabilities or limitation of persons involving construction works are inevitable. Due to worker limitation and employment rate, it may be impossible for contractors in different locations to find skilled workers for causing problems and obstacles e.g., late or delayed work completion, poor work quality or construction method restrictions. Besides, certain construction works or on-site constructions may not be normally operated owing to problems with nearby buildings or environment e.g. control of nuisance or vibration in the area adjacent to hospital, etc.

However, aside from the goal or success in project management for the completion within the budget, schedule and quality, the construction project managers' success based on managerial competencies is also reflected through their career success, which satisfies their personal desire and need. The goal achievement as a result of skill development and work experience (Akrivos et al., 2007) leads to efficient work so project managers' success implies organizational success (Ramaswami et al., 2010). Likewise, career success contributes to advancement, promotion to higher position and remuneration, job satisfaction and organizational commitment. This eventually reduces the rate of absenteeism or resignation and creates the positive impact on career progress and organizational growth (Schneider et al., 2006).

With such importance, it can be said that the development of construction project managers' knowledge, abilities, attributes and job competencies contributes to efficient and uninterrupted operation of construction projects in Lao PDR's construction industry. This is the preparation and development of human resource to support economic expansion and national development, especially in light of promotion and stimulation of investments in the business sector. It is one of the goals in enhancing continuous and stable economic growth of Lao PDR. In addition, Lao PDR government also pays attention to investments in SMEs and to developments of human resource in manufacturing, service and industrial sectors. For this reason, the study of successful construction project managers' competencies will enable Lao 
PDR's construction business and industry to enhance competencies of those managers in conformance with contexts, needs and necessities of constant and sustainable promotion of competencies and potentials of human resource for career advancement and ability to effectively and efficiently manage construction projects under changing and competitive situations.

\section{RESEARCH OBJECTIVES}

To study essential competencies of successful construction project managers in the Lao People's Democratic Republic (Lao PDR)

\section{RESEARCH METHODOLOGY}

The constructivism is for knowledge claim in this research (Creswell, 2009) where the author believes that the truth is diverse and appears in people's minds (Guba, 1990) that there is a relationship between informants and methods of obtaining data. This is the qualitative approach (Cresswell, 2003; Patton, 2002) in which the author can understand sentiments, experiences and opinions of informants. Moreover, phenomenological strategies of inquiry are also used by the author because this study requires answers for describing meanings of people's life experiences in light of specific and suitable concepts or phenomena (Creswell \& Clark, 2007).

This study has 3 groups of key informants: 1) construction project managers of construction companies for the following projects: building and residence construction, general engineering construction (works related to roads, sewers, irrigations, large bridges and airports) and industrial construction, 2) entrepreneurs, executives, project owners and construction project investors, and 3) board of directors of construction association. The author chooses 10 of them using purposive sampling method on the basis of key informant size determination principle in qualitative research in which the phenomenology is applied (Boontham Kijpreeda, 2008; Kuzel, 1999, cited in B. Marshall et al., 2013). Its tools include the interview and content analysis forms verified in terms of content validity and language use by senior experts. The In-depth interviews are conducted accordingly. Additionally, the author explores and acquires additional data on competencies from relevant books, articles and research from domestic and international sources so that research results can be used in the most appropriate context. The author categorizes and summarizes the interviewed data for analysis purpose (Miles \& Huberman, 1984) to ensure their accuracy and to draw research conclusions (Corbin \& Strauss, 2008). With respect to rigor criteria, the author performs the triangulation of findings and interpretation of collected data for greater reliability (Lincoln \& Guba, 1985).

\section{STUDY RESULTS}

The data analysis shows that elements of competencies of successful construction project managers in Lao PDR can be divided into two categories:

1) Core competency of construction project managers:

Knowledge (accounting, finance, computer, digital literacy and information technology, construction engineering, personnel management, laws, project planning purchasing and warehouse management, risk management, understanding of construction project organizations)

Skills/competencies (cost management, work management, time management, qualityoriented management, project management, stakeholder management, communication, coordination, process improvement and strategic thinking) 
Attributes (ability to constantly engage in self-development, job responsibilities, reliability, ethics and integrity, flexibility and adaptability, participation and teamwork emotional control and personality and safety consciousness)

2) Successful competency of construction project managers:

Knowledge (business development knowledge, counseling knowledge, business process knowledge, credit knowledge, internal audit knowledge)

Skills/abilities (critical thinking, budget management, change management, conflict management, decision-making, empowerment, prediction/forecasting, targeting, having influence over others, initiation, leadership, network building, incentives and rewards, strategic acumen, team building, vision, data searching, language use, motivating others, negotiation and bargaining, performance management and personal/professional relationships)

Attributes (being success-oriented, rules/regulations compliance, enthusiasm, being resultoriented, self-confidence, stress tolerance and faith building)

\section{DISCUSSION}

Respecting the situation of operating a construction project, it can be said that the problem is caused by management, which is related to human resource. Indeed, the human resource is a key factor in the operation or project because each construction project needs numerous personnel, work and multi-department coordination. Hence, the personnel with jobappropriate knowledge and competencies are indispensable for success of assigned tasks or fulfillment of project goals. Besides, in construction project management, it is necessary to have a person representing project owners in the coordination and management of the construction project or so-called the "project manager" (Lindahl \& Ryd, 2007). This is an important person playing a key role (as team leader, expert, collaborator and advisor, etc.) for efficient project management. Many political, economic, social and technological factors, trade liberalization, environmental conservation and global information system integration result in rapid changes and pressures of competitive situation in recent years. This can be both an opportunity and an obstacle to the operation of construction project; therefore, for construction project management, the construction project managers lie at heart of project success. The manager must possess knowledge, skills and competencies (McClelland, 1976; Spencer \& Spencer, 1993) required for construction project management and work ethically and honestly on the basis of mutual trust and no corruption (Phiphob Udon, 2012). This is to produce work that most satisfies stakeholders and is accepted by society. The improvement of process for more efficiency increases the organizational abilities to deal with changes, which are regarded as a risk in organizational management (Apichai Srimuang, 2010).

Construction project managers' core competencies include knowledge (accounting, finance, computer, digital literacy and information technology, construction engineering, personnel management, laws, project planning purchasing and warehouse management, risk management, understanding of construction project organizations). This is consistent with the study of Krittachon Wongrat et al., (2012), Chanual Euarkarn (2014), Pinit Boonnithidilik et al. (2018), Ingason \& Jónasson (2009) and PMI (2013). Besides, the aspect of skills/competencies (cost management, work management, time management, quality-oriented management, project management, stakeholder management, communication, coordination, process improvement and strategic thinking) agrees with the studies of Chanual Euarkarn (2014) Pinit Boonnithidilik et al. (2018), Natthaporn Chaiprasert (2019), PMI (2007) and Ingason \& Jónasson (2009). Lastly, the issue of attributes (ability to constantly engage in selfdevelopment, job responsibilities, reliability, ethics and integrity, flexibility and adaptability, participation and teamwork emotional control and personality and safety consciousness) are 
found to be in line with Fisher's study (2011) on the ability to constantly engage in selfdevelopment, job responsibilities as well as ethics and integrity.

The construction project managers' successful competencies including knowledge (business development knowledge, counseling knowledge, business process knowledge, credit knowledge, internal audit knowledge) conform to the studies PMI (2013) and Jabar et al., (2013). Furthermore, there is a consistency between the aspect of skills/abilities (critical thinking, budget management, change management, conflict management, decision-making, empowerment, prediction/forecasting, targeting, having influence over others, initiation, leadership, network building, incentives and rewards, strategic acumen, team building, vision, data searching, language use, motivating others, negotiation and bargaining, performance management and personal/professional relationships) and the studies on leadership and network building by Geoghegan \& Dulewicz (2008) and Moradi et al. (2020). Lastly, the attributes (being success-oriented, rules/regulations compliance, enthusiasm, being resultoriented, self-confidence, stress tolerance and faith building) conform to the issues of being success-oriented and being result-oriented in the study of Dziekonski (2017).

\section{CONCLUSION AND RECOMMENDATIONS}

The construction projects play a role in Lao PDR's economic expansion and are a key factor in driving national development in achieving goals of the 8th National Economic and Social Development Plan. Due to the importance of construction industry to Lao PDR's economy, the construction enterprise or business needs to be prepared and adapted to the ongoing external and internal factors. The enhancement of construction project managers' knowledge, competence, attributes and job-appropriate competencies will thus contribute to the efficient and uninterrupted operation of construction projects in construction industry of Lao PDR. This reflects the preparedness and human resource potential development to accommodate to economic growth and national development. Therefore, the development of construction project managers' competencies affects the project success; therefore, the construction project managers must have knowledge, skills, or competencies appropriate for the job to accomplish assigned tasks or project goals. However, the results of this study reveal core competencies and achievement competencies required for the initial success of construction project managers. This can then be used in the development of a competency model for improvement of construction project managers' performance in consistent with contexts, needs and necessities. All these eventually lead to higher potentials, augmentation of human resource capabilities and job advancement resulting in continual and sustainable promotion of efficient and effective construction project management under the changing and competitive situation.

\section{REFERENCES}

[1] Al-Hammad, A. M. (2000). "Common interface problems among various construction parties." Journal of Performance of Constructed Facilities. 14(2): 71-74

[2] Akrivos, C. (2007). "Corporate top management. Career success factors: the case of Greek tourism industry", $\mathrm{PhD}$ thesis, University of Piraeus, Piraeus.

[3] Apichai Srimuang. (2010). Strategies for Human Resource Management in an Economic Crisis. Bangkok: HR Center.

[4] Chau, V. S., \& Kao, Y. Y. (2009). Bridge over troubled water or long and winding road? gap-5 in airline service quality performance measures. Managing Service Quality, 19(1), 106-134.

[5] Chanual Euarkarn. (2014). Development of core competencies of Thai engineers in preparing for ASEAN in 2018. 2015 Kasem Bundit Journal, Year 15, Issue 1, January - June 2014. 
[6] Corbin, J., \& Strauss, A. (2008). Basics of Qualitative Research: Techniques and Procedures for Developing Grounded Theory (3rd ed.). Thousand Oaks, CA: SAGE.

[7] Cresswell, J.W. (2003). Research Design: Qualitative, Quantitative, and Mixed Methods Approaches (2nd ed.). Thousand Oaks, CA: Sage.

[8] Cresswell, J.W. (2009). Research Design: Qualitative, Quantitative, and Mixed Methods Approaches (3rd ed.). Thousand Oaks, CA: Sage.

[9] Creswell, J. W., \& Plano Clark, V. L. (2007). Designing and Conducting Mixed Methods Research. Thousand Oaks, CA: Sage.

[10] Deming, W.E. (1982). Quality, productivity and competitive position, Cambridge, MA: MIT Press, Massachusetts Institute of Technology, Centre for Advanced Engineering

[11] Department of Import-Export Ministry of Industry and Trade, Lao PDR. (2016). Import-Export Statistics 2015 - 2016. Vientiane: Department of Import-Export Ministry of Industry and Trade

[12] Department of Public Works and Town \& Country Planning, Lao PDR, (2017) Construction Industry Planning for Lao PDR. Vientiane: Department of Public Works and Town \& Country Planning.

[13] Donal, B. S. \& P. C. Boyd (2016). Professional Construction Management. Singapore, McGraw-Hill.

[14] Dziekonski, Krzysztof. (2017). Project Managers' Competencies Model for Construction Industry in Poland. Procedia Engineering. 182. 174-181.

[15] 10.1016/j.proeng.2017.03.157.

[16] Fisher, E. (2011) 'What practitioners consider to be the skills and behaviours of an effective people project manager', International Journal of Project Management, 29(8), pp. 994-1002.

[17] Geoghegan, L., \& Dulewicz, V. (2008) 'Do project managers' leadership competencies contribute to project success? Project Management Journal, 39(4), pp. 58-67.

[18] Guba, E. G. (1990). The alternative paradigm dialogs. In Guba, E.G. (Ed.). The Paradigm Dialog. (pp.45-57). Newbury Park, CA: Sage.

[19] Halpin, D. W. \& Senior, B. A. (2012). Construction Management. Asia, John Wiley \& Sons

[20] Heywood, L., Gonczi, A., \& Hager, P. (1992). A Guide to Development of Competency Standards for Professions, A.G.P.S.: Canberra.

[21] International Monetary Fund (2018). World Economic Outlook, October 2017: Seeking Sustainable Growth: Short-Term Recovery, Long-Term Challenges. (Online). Retrieved June 15, 2018, form: http://www.imf.org/external/datamapper/datasets/WEO

[22] Ingason, H., \& Jónasson, H. (2009) 'Contemporary knowledge and skill requirements in project management', Project Management Journal, 40(2), pp. 59-69.

[23] Iyer, K. C. and Jha, K. N. (2005). "Factors affecting cost performance: evidence from Indian construction projects." International Journal of Project Management, 23(4): 283-295.

[24] Jabar, Izatul., Ismail, Faridah., Aziz, Nurmardhiyah \& Janipha, Nurul. (2013). Construction Manager's Competency in Managing the Construction Process of IBS Projects. Procedia Social and Behavioral Sciences. 105. 85-93. 10.1016/j.sbspro.2013.11.010.

[25] Krittachon Wongrat Teerawut Bunyasopon Wichienketsing and Niphon Suraphong Rakcharoen (2012). Development of Performance Manager of Production Manager in Electrical and Electronics Industry. Journal of King Mongkut's University North Bangkok, Vol. 22, No. 1 Jan.-Apr. 2012.

[26] Lincoln, Y.S., \& Guba, E.G. (1985). Naturalistic Inquiry. Beverly Hills, CA: Sage. 
[27] Lindahl, G. \& Ryd, N. (2007). "Clients' goals and the construction project management process." Construction Project Management 25(3/4): 147-156.

[28] Liu, G., Q. Shen, H. Li and L. Shen (2004). "Factors constraining the development of professional project management in China's construction industry." International Journal of Project Management, 22(3): 203-211.

[29] Marshall, B., Cardon, P., Poddar, A., \& Fontenot, R. (2013). Does sample size matter in qualitative research? A review of qualitative interviews in IS research. Journal of Computer Information Systems, 54, 11- 22. doi:10.1080/08874417.2013.11645667

[30] McClelland DC. (1976). The achieving society. Irvington Publishers, New York

[31] Miles, M., \& Huberman, A.M. (1994). Qualitative Data Analysis. Thousand Oaks, CA: Sage Publications.

[32] Ministry of Industry and Trade. (2017). Construction industry in the Lao PDR 2016. Vientiane: Ministry of Industry and Trade, Lao PDR.

[33] Moradi, Sina., Kähkönen, Kalle \& Aaltonen, Kirsi. (2020). Project Managers' Competencies in Collaborative Construction Projects. Buildings. 10. 10.3390/buildings10030050.

[34] Natthaporn Chaiprasert (2019) Competencies of Human Resources Manager in relation to the Efficiency and Performance of Manufacturing Factory Personnel, Pathum Thani Province Academic Journal, Suvarnabhumi Institute of Technology, Vol. 4, Special Issue (2018).

[35] Ng, T., Eby, L., Sorenson, K., \& Feldman, D. (2005). Predictors of objective and subjective career success. Personnel Psychology, 58, 367-408.

[36] Office of the Prime Minister of Lao PDR. (2017). National Policy for Lao PDR. Vientiane: Office of the Prime Minister.

[37] Patton, M.Q. (2002). Qualitative Research and Evaluation Methods. Thousand Oaks, CA: Sage.

[38] Phanomphai Naipai. (1999). Construction management. Pimluk, Bangkok: Industrial Techniques Support Textbook. Technology Promotion Association (Thai-Japanese).

[39] Phiphob Udon. (2012). Development of small and medium enterprises. Bangkok: Thammasat University.

[40] Pinit Boonnithidilik, Akekapop Simchai and Pornthip Chummuangpak (2018) Development of competency in civil engineering professionals in the Bangkok and suburbs to prepare for the ASEAN Economic Community Research and Development Journal Chiang Mai Rajabhat University, Year 13, Issue 46, October - December 2018.

[41] PMI. (2007). Project Manager Competency Development Framework, 2nd ed, PMI.

[42] PMI. (2013). A Guide to the Project Management Body of Knowledge, 5th ed, Project Management Institute, PMI.

[43] PMI. (2013) 'The High Cost of Low Performance: The Essential Role of Communications', PMI's Pulse of The Profession In-Depth Report, pp. 1 - 10.

[44] Ng, T., Eby, L., Sorenson, K., \& Feldman, D. (2005). Predictors of objective and subjective career success. Personnel Psychology, 58, 367-408.

[45] Ramaswami, Aarti \& Dreher, George \& Bretz, Robert \& WIETHOFF, CAROLYN. (2010). Gender, mentoring, and career success: The importance of organizational context. Personnel Psychology. 63. 385 - 405. 10.1111/j.1744-6570.2010.01174.x.

[46] Sakthai Surakitbowon (2014). Critical competencies of professional management. Journal of Sakon Nakhon Rajabhat University, Year 6, Issue 12 July - December 2014 
[47] Schreiber,J.B., Nora,A., Stage,F., Barlow, E. A.,\& King, (2006). Reporting structural equation modeling and confirmatory factor analysis results: A review. The Journal of Educational Research, 99(6),323-337.

[48] Shebob, A. \& Dawood, Nashwan \& Xu, Qiang. (2011). Analysing construction delay factors: A case study of building construction project in Libya. Association of Researchers in Construction Management, ARCOM 2011 - Proceedings of the 27th Annual Conference. 2. 1005-1012.

[49] Siam University. (2010). Small and medium enterprise secondary information foundation project. Construction industry field. Bangkok: Office of Small and Medium Enterprises Promotion (OSMEP).

[50] Spencer, Lyle M. \& Spencer, Signe M. (1993). Competency at work: Models for Superior Performance. New York: John Wiley \& Sons.

[51] Thai Business Information Center in Laos. (2017). Summary of construction progress of the Lao-Chinese railway. (Online system): Retrieved on June 10, 2018 from http://www.thaibizlao.com/lao/news/detail.php?id=20868

[52] The Engineering Institute of Thailand. (2009). Construction project management. Bangkok: Printing House, Council of Engineers, Mahidol University.

[53] World Bank Group. (2017). Ease of doing business index. [Online]. Retrieved June 15, 2018, form: https://data.worldbank.org/indicator/IC.BUS.EASE.XQ 